\author{
S.I. Nichkalo, M.V. Shepida, M.V. Chekaylo
}

\title{
Optimal Conditions for the Deposition of Gold Nanofilms on a Silicon by Galvanic Replacement Method
}

\author{
Lviv Polytechnic National University, 79013,_Lviv, Ukraine, maryana_shepida@ukr.net
}

\begin{abstract}
The formation conditions of gold nanofilms on silicon ( $\mathrm{Si}$ ) substrate by galvanic replacement in a dimethyl sulfoxide (DMSO) solvent and their subsequent use for the fabrication of Si nanostructures by metal-assisted chemical etching (MACE) method were under study. It was found that the average size and number of Au nanoparticles increase with an increase in the reducible metal ion concentration from 2 to $8 \mathrm{mM} \mathrm{HAuCl}_{4}$ in DMSO, whereas the distribution of Au nanoparticles in height remains low for all concentrations of the reducible metal. In the temperature range $40-70^{\circ} \mathrm{C}$, a different morphology of the deposited Au nanofilms observed. In particular, at $40{ }^{\circ} \mathrm{C}$, the film is porous mainly homogeneous, whereas at a temperature of $50^{\circ} \mathrm{C}$ the film is rougher. The subsequent rise in temperature from $60^{\circ} \mathrm{C}$ to $70^{\circ} \mathrm{C}$ results in the formation of Au nanofilm with a discontinuous morphology. It was established that regardless of the morphology of deposited Au nanofilms, the $\mathrm{Si}$ nanostructures maintain a vertical orientation to the plane of the Si substrate during MACE-etching. The produced Si nanostructures were $1.5-2.5 \mu \mathrm{m}$ in height and their average diameter ranged from 100 to $300 \mathrm{~nm}$. etching.

Key words: galvanic replacement, nanoparticles, gold film, silicon nanostructures, metal-assisted chemical
\end{abstract}

Стаття поступила до редакиії 15.07.2019; прийнята до друку 15.09.2019.

\section{Introduction}

Nanoparticles of gold (AuNPs) are known to be a promising material in terms of their application in biomedicine as biosensors [1-3], biomarkers [4, 5], and for bioimaging [6,7], drug delivery [8,9] etc. Additionally, AuNPs deposited onto Si substrate exhibit surface plasmon resonance [10] which might help to improve overall catalytic property of Si-based materials and thereby enhance performances of devices based on such materials, e.g. solar cells [11]. On the other hand, $\mathrm{Au}$ nanofilms are used in a wide range of applications, e.g. micro- and nanoelectronics, as well as for the formation of silicon nanostructures of different morphologies (nanopores, nanowires, nanopillars etc.) [12-14]. The deposition method and the control of morphology of deposited gold nanoparticles and nanofilms are known to be urgent tasks [15]. Thus, widely studied physico-chemical methods of deposition are carried out mainly in aqueous solutions, in which besides the main process of metal reduction, there are side processes, in particular the release of hydrogen in the cathode regions and the decomposition of the substrate on which the particles or films are deposited. This issue complicates controlled formation of metal nanoparticles, which is a necessary condition for surface modification. In contrast, utilizing the galvanic repalcement in the medium of organic aprotic solvents, e.g. DMSO can prevent the occurrence of these disadvantages, as it was shown in $[15,16]$.

In our previous work we demonstrated that an increase in temperature of solution containing $\left[\mathrm{AuCl}_{4}\right]^{-}$ ions and its concentration causes the size enlargement of AuNPs [17]. However, the effect of the morphology of $\mathrm{Au}$ sediment deposited onto $\mathrm{Si}$ substrate in a DMSO solvent by galvanic replacement method on the formation of Si nanostructures by means of MACE method was not considered. Therefore, the aim of this work is to study the formation conditions of gold nanofilms by galvanic replacement method in a DMSO solvent, and their subsequent use for the fabrication of silicon nanostructures by MACE method.

\section{Materials and Methods}

In our experiments the p-type (100) oriented $\mathrm{Si}$ substrates with resistivity $12 \Omega \times \mathrm{cm}$ were used. Substrate was cut into equal samples with about $1 \times 1 \mathrm{~cm}^{2}$ square in dimension. Samples were preliminary degreased in acetone, washed in ultrasonic bath containing ethanol for $280 \mathrm{~s}$ and etched in $5 \%$ aquous solution of hydrofluoric acid (HF) in order to remove a native oxide layer. Deposition of gold onto the $\mathrm{Si}$ samples surface was conducted by galvanic replacement method using $\mathrm{HAuCl}_{4}\left(\mathrm{HAuCl}_{4} \cdot 3 \mathrm{H}_{2} \mathrm{O}, 99.99 \%\right.$, Alfa Aesar) solution 
with molar concentration of $0.002-0.008 \mathrm{M}$ mixed with HF (1 \% mass) and DMSO (99\%, Alfa Aesar). Clean Si samples were immersed in a metal salt solution at temperature $40-70{ }^{\circ} \mathrm{C}$ for $1 \mathrm{~min}$. Afterwards, Si samples covered with $\mathrm{Au}$ nanoparticles were consequently washed in ethanol, acetone and then dried in a heat chamber at temperature $60{ }^{\circ} \mathrm{C}$. Si nanostructures were produced by MACE method. For this, Si samples with pre-deposited $\mathrm{Au}$ nanoparticles dipped into the etching solution of $\mathrm{HF}(40 \%) / \mathrm{H}_{2} \mathrm{O}_{2}(35 \%) / \mathrm{H}_{2} \mathrm{O}$ (4/1/4). The etching process was carried out at room temperature for $15 \mathrm{~min}$. Finally, all the samples were rinsed with deionized water and dried in a heat chamber at temperature $80^{\circ} \mathrm{C}$.

The surface morphology of Si samples was studied with using the scanning electron microscopes (SEM) ZEISS EVO 40XVP, SELMI REM-106I, and the atomic force microscope (AFM) Solver P47-PRO. Typically the accelerating voltage of the SEM was about $20 \mathrm{keV}$.

\section{Results and Discussion}

According to the results of AFM studies, nanoparticles of gold in the height of 5 to $50 \mathrm{~nm}$ were found on the surface of $\mathrm{Si}$ samples (Fig. 1). As can be seen, the average size and number of $\mathrm{Au}$ nanoparticles increase with an increase in the reducible metal ion concentration from 2 to $8 \mathrm{mM} \mathrm{HAuCl}_{4}$ in DMSO. At the
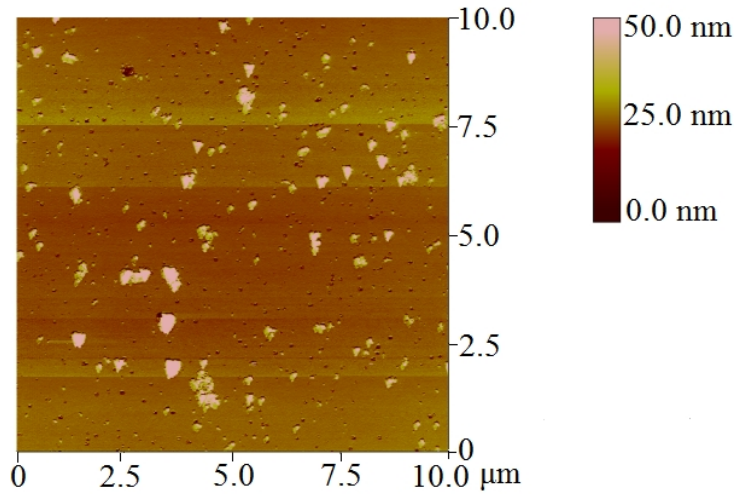

(a) same time, the distribution of Au nanoparticles in height remains low for all concentrations of the reducible metal. The process of galvanic replacement of gold can be described by the following redox reactions [17]:

$$
\mathrm{nSi}+4 \mathrm{Me}^{\mathrm{n}+} \rightarrow \mathrm{nSi}^{4+}+4 \mathrm{Me},
$$

where at the anode a reaction (2) is taking place:

$$
\mathrm{Si}+6 \mathrm{~F}-\rightarrow \mathrm{SiF} 62-+4 \mathrm{e}, \quad \mathrm{E} 0=-1.20 \mathrm{~V}
$$

and consequently at the cathode (3):

$$
[\mathrm{AuCl} 4]-+3 \mathrm{e} \rightarrow \mathrm{Au}+4 \mathrm{Cl}-, \mathrm{E} 0=1.42 \mathrm{~V}
$$

A high value of the potential difference between the reducible metal and silicon causes high values of the cathode current density and etching rate of the total reaction (1) as well. Therefore, considering that the electromotive force of the process is $\Delta \mathrm{E}^{0}=2.62 \mathrm{~V}$, the reduction rate of $\mathrm{Au}$ on the silicon surface will be higher than in case of using metals with low values of the standard electrode potential such as $\mathrm{Ag}, \mathrm{Pd}, \mathrm{Ru}, \mathrm{Cu}, \mathrm{Ni}$ etc.

Another important factor influencing the morphology of Si surface covered with Au nanoparticles which have been deposited by galvanic replacement method is the temperature. The results of studies have shown that in the temperature range from 40 to $70{ }^{\circ} \mathrm{C}$, a different morphology of $\mathrm{Au}$ nanofilms can be observed (Fig. 2). In particular, at $40{ }^{\circ} \mathrm{C}$ the film is porous mainly homogeneous (Fig. 2, a), whereas at a temperature of $50{ }^{\circ} \mathrm{C}$ the film is rougher (Fig. 2, b). With the subsequent
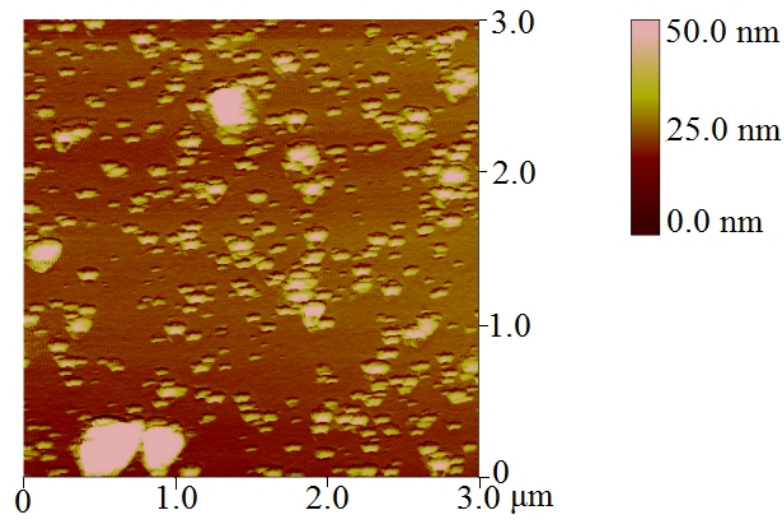

(b)
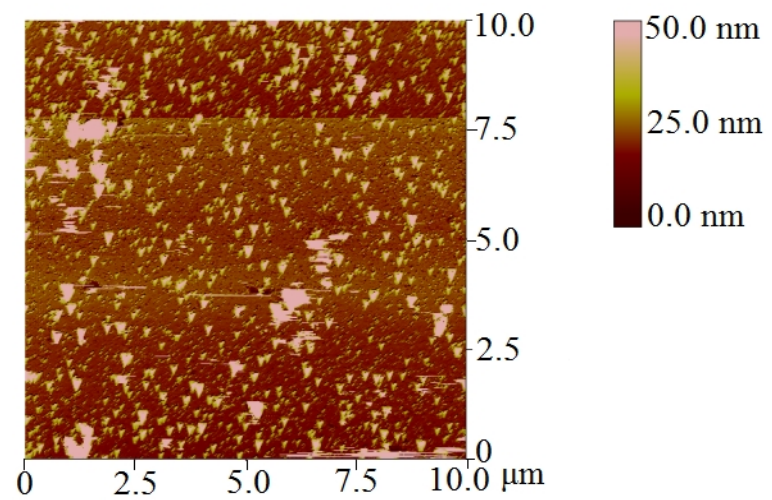

(c)

Fig. 1. AFM images of the Au nanoparticles deposited on the Si substrate from a solution, which contained $2 \mathrm{mM}$ (a), $4 \mathrm{mM}$ (b) and $8 \mathrm{mM}$ (c) of $\mathrm{HAuCl}_{4}$ in DMSO at temperature $50{ }^{\circ} \mathrm{C}$ for $1 \mathrm{~min}$. 


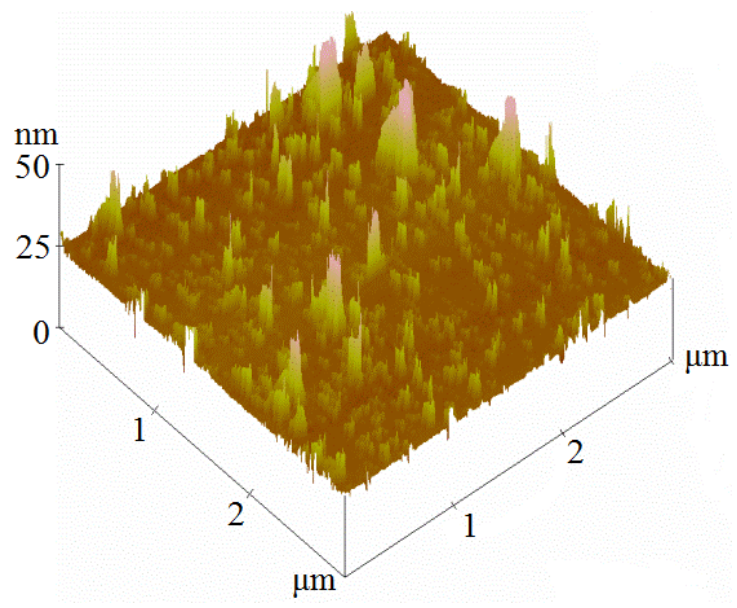

(a)

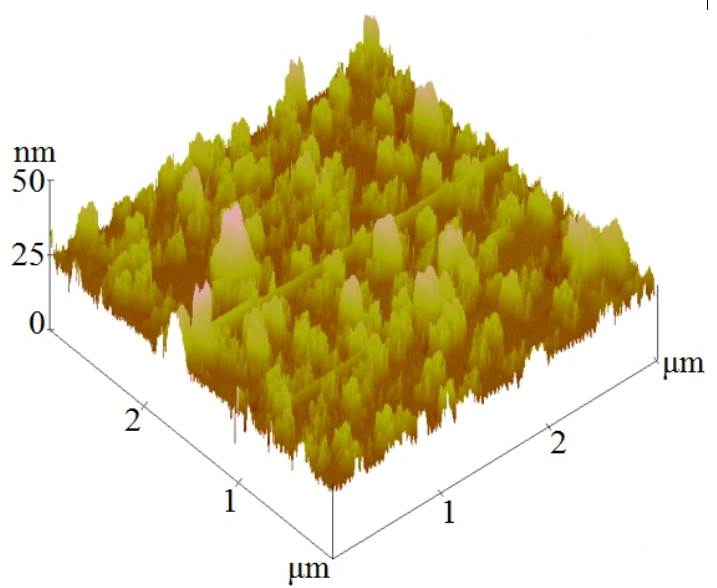

(c)

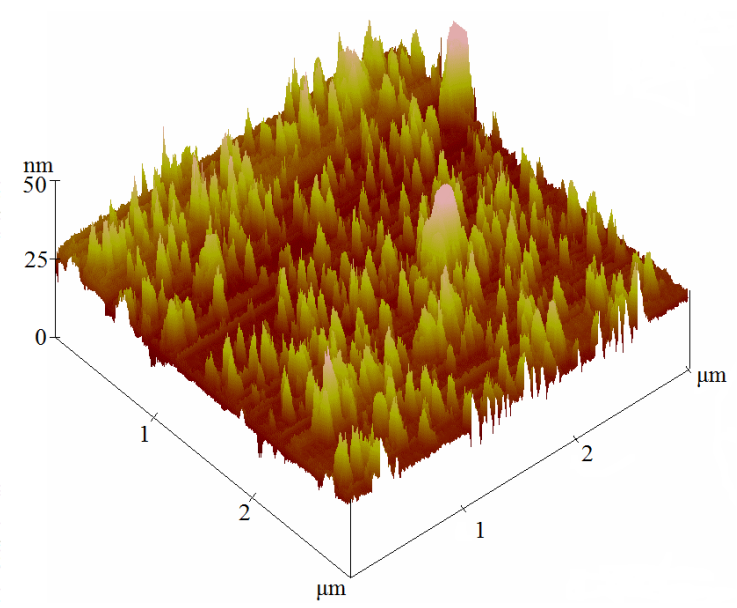

(b)

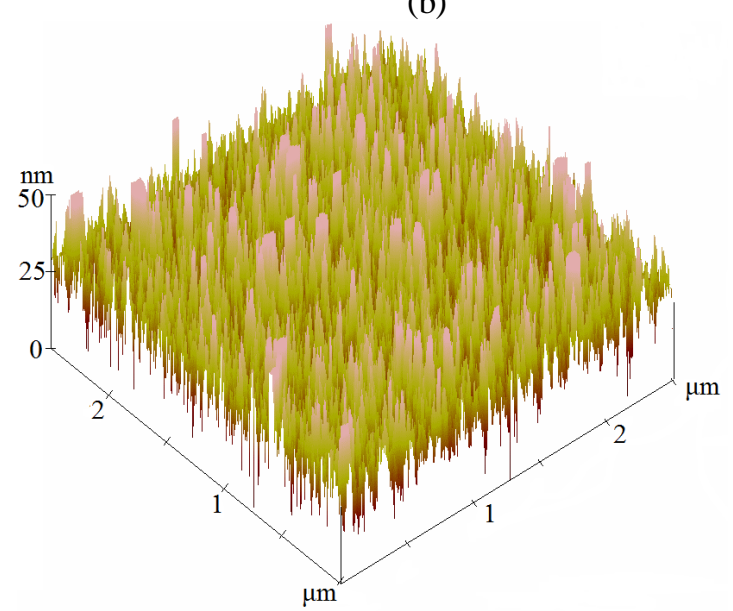

(d)

Fig. 2. Dependence of the average size of Au nanoparticles on the temperature of the galvanic replacement process:

$40{ }^{\circ} \mathrm{C}(\mathrm{a}), 50^{\circ} \mathrm{C}(\mathrm{b}), 60^{\circ} \mathrm{C}(\mathrm{c}), 70^{\circ} \mathrm{C}(\mathrm{d})$.

rise in temperature from $60{ }^{\circ} \mathrm{C}$ (Fig. 2, c) to $70{ }^{\circ} \mathrm{C}$ (Fig. 2, d), the adsorption of DMSO molecules with gold nanoparticles is reduced. In other words, the deterrent effect of surface complexes on the size growth of $\mathrm{Au}$ nanoparticles decreases [16], which results in an increase in their size and therefore the growth of Au nanofilm the morphology of which becomes discontinuous. Thus, the size dependence of deposited nanoparticles on temperature is linear in the range $50-70{ }^{\circ} \mathrm{C}$ (Fig. 2).

The results of studies on the effect of temperature on the Au nanoparticle height obtained are similar to those concerning the change in the reducible metal ion concentration. In particular, the results of the AFM studies showed that with a rise in temperature from 40 to $70{ }^{\circ} \mathrm{C}$ an increase in the average size of gold nanoparticles, their height and the surface filling density is observed (Fig. 3). Consequently, the main factors influencing the filling of the $\mathrm{Si}$ substrate surface with gold nanoparticles are the changes in the reducible metal ion concentration and temperature of the galvanic replacement process.

The next stage of this study was to determine the effect of the change in the morphology of gold nanofilm deposited by galvanic replacement, on the formation process of Si nanostructures during MACE-etching. Such a process takes place under the electrochemical mechanism, where the surface of the $\mathrm{Au}$ particle contacting with an etchant, acts as a cathode, and consequently, the interface of Au particle/Si surface is an anode. Between the anode and the cathode there is a potential difference which makes electrons to flow. Thus, there is a local flow of current in the direction from the cathode to the anode.

As it is known [13], gold nanofilms provoke anisotropic etching of a Si substrate mainly along the (100) direction. In addition, due to the high stability of $\mathrm{Au}$ in the etching solution, the Si nanostructures with a high aspect ratio can be produced [12,13, 18]. Indeed, as it can be seen in Fig. 4, regardless of the morphology of deposited gold nanofilms, the Si nanostructures maintain a vertical orientation to the plane of the $\mathrm{Si}$ substrate during MACE-etching, and their height ranges from 1.5 to $2.5 \mu \mathrm{m}$. The lateral dimension of $\mathrm{Si}$ nanostructures can be estimated from Fig. 4, a. Thus, the average diameter of the produced $\mathrm{Si}$ nanostructures ranges from 100 to $300 \mathrm{~nm}$. It is hard to define however the average lateral size of nanostructures presented in Fig. 4, b as they are irregular and densely packed to each other. 


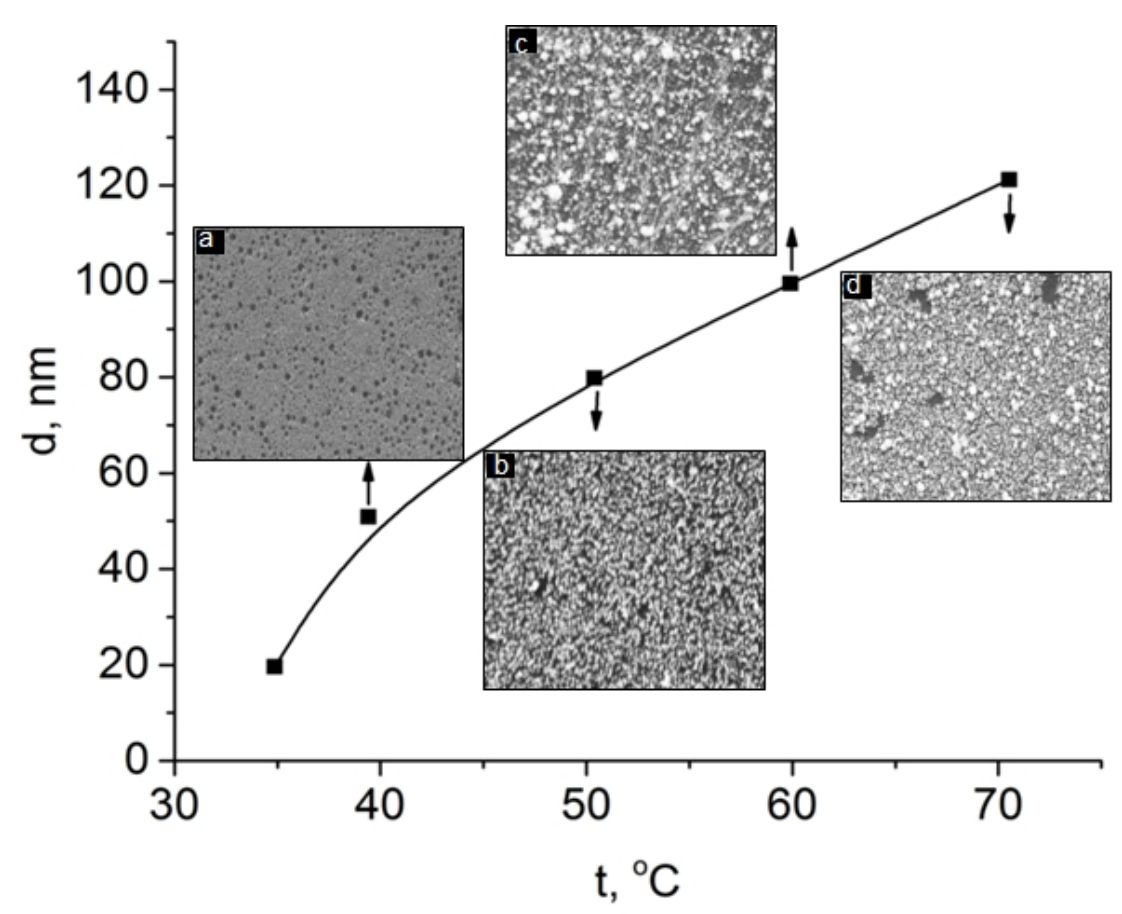

Fig. 3. AFM images of gold nanoparticles deposited on the $\mathrm{Si}$ substrate from a solution, which contained $4 \mathrm{mM}$ of $\mathrm{HAuCl}_{4}$ in DMSO for $1 \mathrm{~min}$ at temperature: $40^{\circ} \mathrm{C}(\mathrm{a}), 50{ }^{\circ} \mathrm{C}(\mathrm{b}), 60^{\circ} \mathrm{C}(\mathrm{c}), 70^{\circ} \mathrm{C}(\mathrm{d})$.

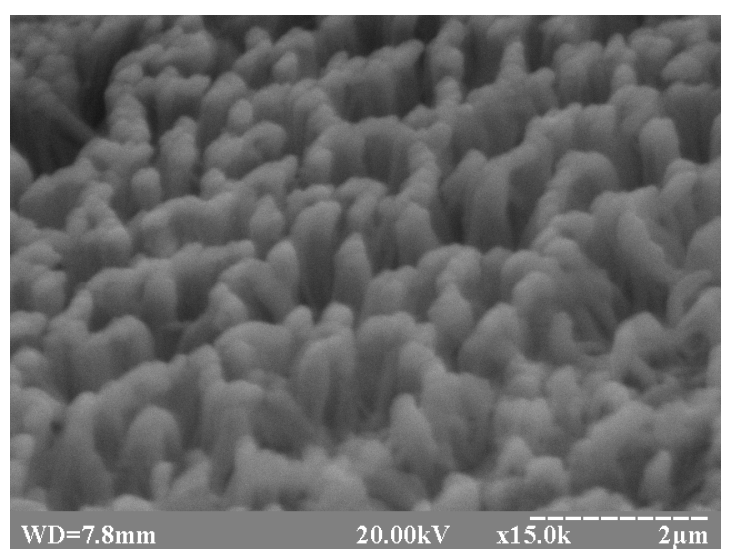

(a)

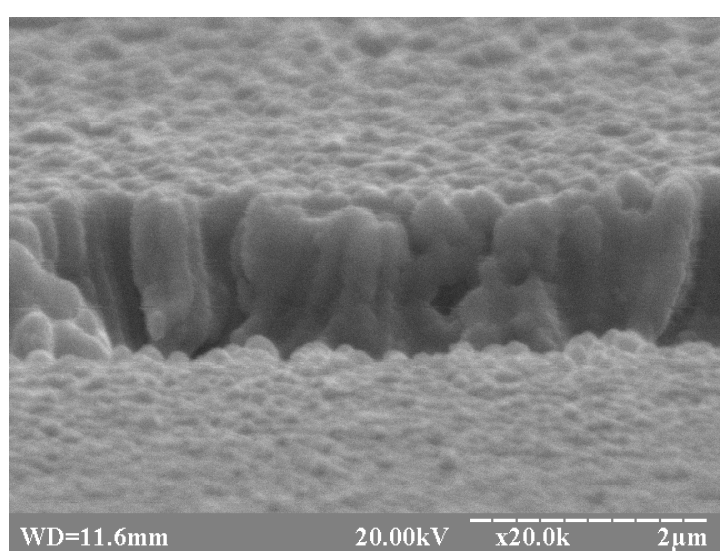

(b)

Fig. 4. SEM images of $\mathrm{Si}$ nanostructures formed after the $15 \mathrm{~min} \mathrm{HF}-\mathrm{H}_{2} \mathrm{O}_{2}-\mathrm{H}_{2} \mathrm{O}$ etching of p-Si(100) substrate coated with Au nanofilms deposited from a solution of $4 \mathrm{mM} \mathrm{H}\left[\mathrm{AuCl}_{4}\right]$ at $50{ }^{\circ} \mathrm{C}$ (a) and $70{ }^{\circ} \mathrm{C}$ (b).

\section{Conclusions}

The experimental results shows that the main factors influencing the geometry of gold nanoparticles, which determine the morphology of the resulting film, are the composition of a solution, the reducing metal ion concentration, and temperature. It was found that the average size and number of $\mathrm{Au}$ nanoparticles increase with an increase in the reducible metal ion concentration from 2 to $8 \mathrm{mM} \mathrm{HAuCl}_{4}$ in DMSO solvent. At the same time, the distribution of $\mathrm{Au}$ nanoparticles in height remains low for all concentrations of the reducible metal.
The temperature influences the morphology of the deposited $\mathrm{Au}$ nanofilms. At temperature $40^{\circ} \mathrm{C}$, the film is porous mainly homogeneous and at a higher temperature of $50{ }^{\circ} \mathrm{C}$ the film becomes rougher. The subsequent rise in temperature from 60 to $70{ }^{\circ} \mathrm{C}$ results in the formation of $\mathrm{Au}$ nanofilm with a discontinuous morphology. The size dependence of the deposited $\mathrm{Au}$ nanoparticles on temperature is found to be linear. There was no significant effect of the morphology of $\mathrm{Au}$ nanofilms on the orientation of $\mathrm{Si}$ nanostructures produced by MACE method. It was found that these $\mathrm{Si}$ nanostructures which were $1.5-2.5 \mu \mathrm{m}$ in height and $100-300 \mathrm{~nm}$ in diameter, maintained perpendicular to the plane of the Si substrate after the MACE-etching. 
Nichkalo S.I. - Candidate of Science (Engineering), Senior Researcher, Department of Semiconductor Electronics;
Shepida M.V. - post-graduate student of the Department of Chemistry and Technology of Inorganic Substances; Chekaylo M.V. - Ph.D., Research Fellow, Department of Organic Chemistry.

[1] N. Elahi, M. Kamali, M.H. Baghersad, Talanta 184, 537 (2018) (doi: 10.1016/j.talanta.2018.02.088).

[2] G. Maduraiveeran, M. Sasidharan, V. Ganesan, Biosensors and Bioelectronics 103, 113 (2018) (doi: 10.1016/j.bios.2017.12.031).

[3] H.-L. Shuai, K.-J. Huang, Y.-X. Chen, L.-X. Fang, M.-P. Jia, Biosensors and Bioelectronics 89, 989 (2017) (doi: 10.1016/j.bios.2016.10.051).

[4] S. Govindaraju, S. R. Ankireddy, B. Viswanath, J. Kim, K. Yun, Scientific Reports 7, 40298 (2017) (doi: 10.1038/srep40298).

[5] S. Xu, W. Ouyang, P. Xie, Y. Lin, B. Qiu, Z. Lin, G. Chen, L. Guo, Analytical Chemistry 89(3), 1617 (2017) (doi: 10.1021/acs.analchem.6b03711).

[6] D. Yin, X. Li, Y. Ma, Z. Liu, Chemical Communications 53(50), 6716 (2017) (doi: 10.1039/c7cc02247f).

[7] E. Yan, M. Cao, Y. Wang, X. Hao, S. Pei, J. Gao, Y. Wang, Z. Zhang, D. Zhang, Materials Science and Engineering C 58, 1090 (2016) (doi: 10.1016/j.msec.2015.09.080).

[8] M. Sengani, A. M. Grumezescu, V. D. Rajeswari, OpenNano 2, 37 (2017) (doi: 10.1016/j.onano.2017.07.001).

[9] M. Pérez-Ortiz, C. Zapata-Urzúa, G. A. Acosta, A. Álvarez-Lueje, F. Albericio, M. J. Kogan, Colloids and Surfaces B: Biointerfaces 158, 25 (2017) (doi: 10.1016/j.colsurfb.2017.06.015).

[10] R. Liu, Q. Wang, Q. Li, X. Yang, K. Wang, W. Nie, Biosensors and Bioelectronics 87, 433 (2017) (doi: 10.1016/j.bios.2016.08.090).

[11] Q. Gao, X. Zhang, L. Duan, X. Li, W. Lü, Superlattices and Microstructures 129, 185 (2019) (doi: 10.1016/j.spmi.2019.03.028).

[12] S. Nichkalo, A. Druzhinin, A. Evtukh, O. Bratus', O Steblova, Nanoscale Research Letters 12(1), 106 (2017) (doi: 10.1186/s11671-017-1886-2).

[13] G. Liu, K. L. Young, X. Liao, M. L. Personick, C. A. Mirkin, Journal of the American Chemical Society 135(33), 12196 (2013) (doi: 10.1021/ja4061867).

[14] Y. Zhang, W. Chu, A. D. Foroushani, H. Wang, D. Li, J. Liu, C. J. Barrow, X. Wang, W. Yang, Materials 7(7), 5169 (2014) (doi: 10.3390/ma7075169).

[15] A. Lahiri, S.-I. Kobayshi, Surface Engineering 32(5), 321 (2016) (doi: 10.1179/1743294415Y.0000000060).

[16] O. Kuntyi, M. Shepida, L. Sus, G. Zozulya, S. Korniy, Chemistry and Chemical Technology 12(3), 305 (2018) (doi: 10.23939/chcht12.03.305).

[17] M. Shepida, O. Kuntyi, S. Nichkalo, G. Zozulya, S. Korniy, Advances in Materials Science and Engineering 2019, 2629464 (2019) (doi: 10.1155/2019/2629464).

[18] Y. Liu, W. Sun, Y. Jiang, X.-Z. Zhao, Materials Letters 139, 437 (2015) (doi: 10.1016/j.matlet.2014.10.084).

\author{
С.І. Нічкало, М.В. Шепіда, М.В. Чекайло
}

\title{
Оптимальні умови осадження наноплівок золота на кремній методом гальванічного заміщення
}

\author{
Національний університет “Львівська політехніка”, 79013, Львів, Україна, maryana shepida@ukr.net
}

\begin{abstract}
Досліджено умови формування наноплівок золота на кремнієвій $(\mathrm{Si})$ підкладці методом гальванічного заміщення в диметилсульфоксиді (ДМСО) та їх подальше використання для створення наноструктур Si методом метал-каталітичного хімічного травлення (МАCE). Встановлено, що середній розмір і кількість наночастинок Аи зростає зі збільшенням концентрації іонів відновлюваного металу від 2 до 8 ммоль/л $\mathrm{HAuCl}_{4}$ в ДМСО, тоді як розподіл наночастинок Аu за висотою залишається низьким для всіх концентрацій відновлюваного металу. Зміна температури процесу гальванічного осадження в межах від 40 до $70{ }^{\circ} \mathrm{C}$ приводить до зміни морфології нанесених наноплівок Аu. Зокрема, за температури $40{ }^{\circ} \mathrm{C}$ плівка $є$ пористою переважно гомогенною, тоді як за температури $50{ }^{\circ} \mathrm{C}$ - плівка шорсткіша. Подальше підвищення температури від 60 до $70{ }^{\circ} \mathrm{C}$ приводить до формування острівкової наноплівки $\mathrm{Au}$. Встановлено, що незалежно від морфології нанесених наноплівок $\mathrm{Au}$, наноструктури $\mathrm{Si}$ зберігають вертикальну орієнтацію відносно площини підкладки Si під час травлення методом МАСЕ. Виявлено, що висота створених у такий спосіб наноструктур $\mathrm{Si}$ знаходиться в межах від 1,5 до 2,5 мкм, а середній діаметр - від 100 до 300 нм.

Ключові слова: гальванічне заміщення, наночастинки, плівки золота, наноструктури кремнію, метал-каталітичне хімічне травлення.
\end{abstract}

